\title{
GISを活用した数量化理論による斜面崩壊ハザードマップ 作成手法の開発と適用
}

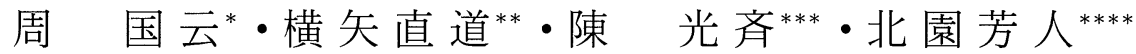

要 旨

本研究では, 近年飛躍的な技術の進歩を遂げた地理情報システム (GIS) と数量化理論を用いた斜面崩壊ハザードマップの新しい作成方法 を提案し，熊本県水俣市集地区をモデル地区として，提案方法による斜面崩壊ハザードマップの作成の実証を行った。従来の数量化理論 によるハザードマップの作成では, 崩壊素因(地質, 傾斜角度, 横断形状, 集水面積, 土地利用等)の空間分布の作成は非常に煩雑で, 解 析に時間が掛かり精度の向上に制約があるため，実用上に問題があった．本研究では，GISの最新入力方法により各素因のデー夕を入力し てラスターデータに変換し，ラスターデータの解析機能を使用することにより短時間で数量化理論解析に必要なアイテム(説明変数)の空 間分布を作成することができる. また数量化理論解析用の標準メッシュをGISで作成し, 説明变数の空間分布値を標準メッシュの属性デー 夕として变換しASCIIの形式で保存し，このASCIIデータを用いて数量化理論による解析を行い，解析結果を標準メッシュにリンクさせハ ザードマップを作成した。この方法を熊本県水俣市集地区の崩壊事例に適用した結果, 短時間で精度の高い斜面崩壊八ザードマップの作 成可能であることが実証された，作成に要した時間は，従来の方法の約 $1 / 10$ の時間であり，入力デー夕の確認・修正・再解析む容易に行 うことができ，提案した方法が精密なハザードマップの作成に極めて有効であることがわかった.

Key words : 斜面崩壊 slope failure, 数量化理論 quantification methods theory, ハザードマップ hazard mapping, 地理情報システム GIS

\section{1.は じめに}

近年，わが国では集中豪雨による斜面崩壊や土石流など の土砂災害が頻繁に発生し大きな社会問題となっている. 過去の 10 年間で合計 6,000 件以上の崖崩れが発生し, 全国 で11万か所以上の急傾斜地崩壊危険箇所が指定されている. そのため, 高い精度と信頼性のある土砂災害八ザードマッ プの作成・整備が住民の安全の確保や経済損失の低減等に 極めて重要な課題となっている.

広域の斜面崩壊ハザードマップの作成に関しては, 力学

*西日本工業大学環境建設学科 Department of Civil and Environmental Engineering, Nishinippon Institute of Technology (会員)

E-mail：zhou@nishitech.ac.jp

**(株)福山コンサルタント Fukuyama Consultants Co. Ltd. (会員)

***九州大学工学府建設システム工学専攻 Department of Civil and Environmental Engineering, Kyushu University

****熊本大学工学部環境システム工学科 Department of Civil and Environmental Engineering, Kumamoto University
モデルが含まれない方法および力学モデルを取り入れる方 法の 2 種類が挙げられる. 力学モデルが含まれない方法と して多変量解析 (数量化理論), 遺伝的アルゴリズム等の統 計的手法が挙げられ，1970年代から現在まで多用されてき

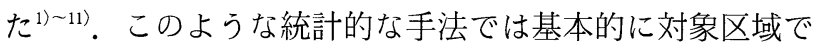
の斜面崩壊に関係する素因 (地質, 傾斜角度, 谷密度, 断 層, 植生, 土地利用分類等) 々外的基準(既崩壊地)の分布 図を作成し，素因と崩壊の関係を統計的に分析し，その関 係に基づいて崩壊危険度の予測図を作成する。ところが， 崩壊の素因である地質, 地形, 植生等の質的な要因は, 量 的な表現が困難であるため, 従来は定量的な扱いができな かった. しかし, 近年の数量化理論の発達 ${ }^{12)}$ とコンピュー 夕技術の飛躍的な発展ととあに，これらの数多くの空間的 に分布する質的な要因を対象として統計的な解析を行うこ とが可能となり, 量的な要因と一緒に扱えるようになって きた。

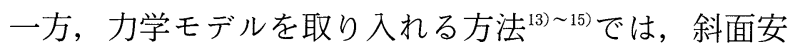
定の力学的なメカニズムを考慮するが, 広域での評価には, 解析に必要な地盤の力学パラメータ, 標高, 傾斜角度, 弱 層の分布および地下水位等の多くの空間情報が要求され, 
データの精度に限界がある。そのため, 広域の斜面崩壊八 ザードマップの作成には, 過去の崩壊履歴と地形, 地質等 の素因を収集・整理し，その関連性を統計的に分析する手 法の方が実用的と考えられる.

しかしながら，これまでの統計的な手法の応用には，地 質, 傾斜角度, 植生, 土地利用分類等の多くの素因と, 崩 壊履歴の空間的な分布を定量的に把握・加工・処理する必 要があった.これらの作業は非常に煩雑で効率が悪く, 入 カデータの精度低下および解析結果の正確性にも影響を与 えて, 実用の面には問題が残されている.

近年, 注目されている地理情報システム(GIS) はさまざ まな分野に急速に応用されてきている，GISは異なる種類 の空間的な情報(図形, 画像, 文字, 数値など)を統合して 管理および解析するッールとして, 地盤防災分野への応用 あ期待できる. また最近, 高精度の航空機レーザー計測に よる地形デー夕, 高解像度衛星デー夕, 道路, 建物分布な どのデジタルデータの整備は多くの地域で行われており, これらのデー夕をGISで取り扱うことで, より効率的で信 頼性の高いハザードマップの作成が可能になると考えられ る.

本研究では, GISを活用した数量化理論による斜面崩壊 ハザードマップ作成の方法を提案し，この方法により熊本 県水俣市集地区の斜面崩壊を対象として, GISデータの入 力, 数量化理論による解析のためのデー夕变換, 解析の実 行, 斜面崩壊ハザードマップの作成および精度の確認を行 い，提案した方法の実用化について検討する.

\section{GISを用いた数量化理論による斜面崩壊ハザード マップの作成方法の提案}

\subsection{GISによる空間データの処理・提供}

空間情報技術としてのGISは，データの取得(Capture)， 格納(Storage)，表示(Display)，管理(Management), 解析 (Analysis) 等の強力なッールとして注目され, さま ざまな分野において応用されてきた，GISのデータモデル としては, 点, 線, 面から構成されるべクトルデータおよ び正方形のセル(メッシュ)の集合体で構成されるラスター データがある(図-1). ベクトルデータは, 土地利用や地質 分布等の境界線が明確で分布が非連続的なものを表現する のに適している. 一方, ラスターデータは, 地形, 地下水 等の広範囲で連続的に変化する現象の表現には便利である. 図-2に示されるように，実世界のさまざまな空間情報の特 性に応じて, ベクトルデータとラスターデータを分けて使 用すべきである.

最近のGIS技術の著しい発展により，これまでは解析事 例の少なかったラスターデータの応用範囲が大きく広げら れてきている. 現在利用されている多くのGISソフトはラ スターデータに対して下記の解析機能を提供している.

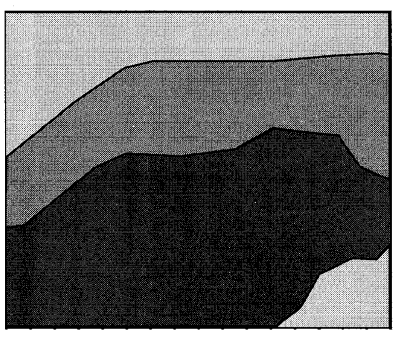

ベクトルデータ

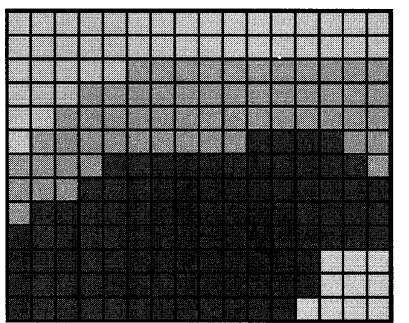

ラスターデータ

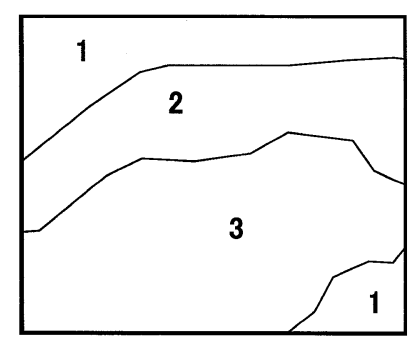

ベクトルデータの属性

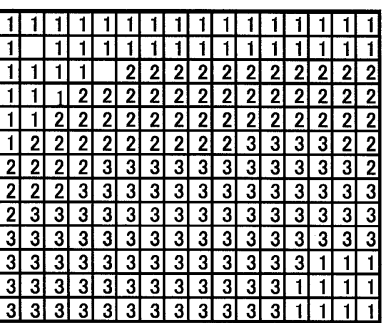

ラスターデータの属性
図-1ＧISのデータモデルと実物の表現の違い

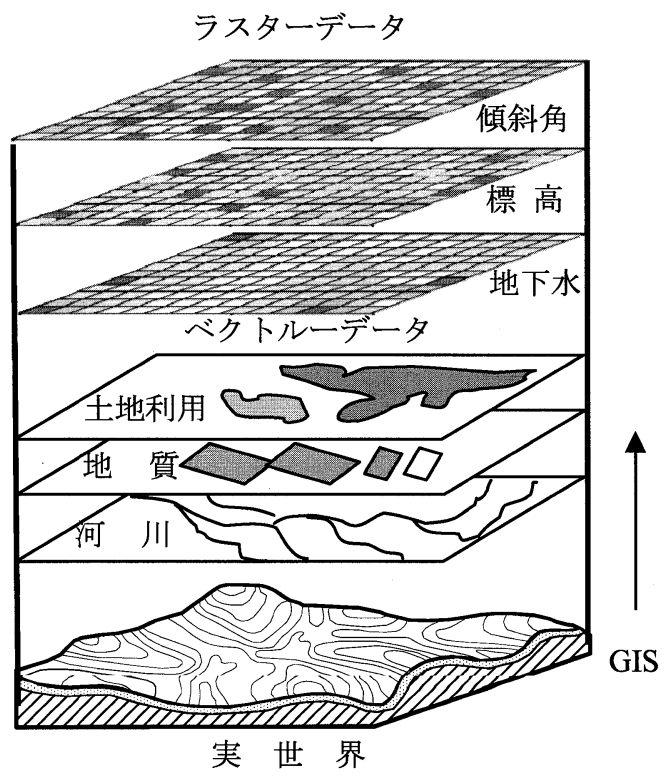

図-2＼cjkstart異なるGISのデータモデルによる実物の表現

1)レイヤーの間の算術計算

2)組み合わせ計算, 論理演算, 集積計算, 代入演算 3)三角関数演算，指数計算，対数計算，分類，統計 4）3D地形解析，標高分布，傾斜方向，傾斜度の計算 5)流出解析，流域の分割之確定，地表面流下の追跡 最近のGISソフトは, ベクトルデータとラスターデータ のデー夕形式の双方向の変換もでき, デー夕の入力と処理 が便利になってきている，本研究では，GISのこのような 空間データの加工・提供・解析の優れた機能を活用し, 斜 面崩壊に関するさまざまな素因のデー夕分布の作成とこれ を用いた解析を効率良く行う方法を提案する.

\section{2 数量化理論による斜面崩壊解析}

危険度の高い斜面の抽出は, 数量化理論のうちの数量化 理論 $\Pi$ 類と呼ばれる判別手法により行い，この手法で崩壊・ 非崩壊の危険度を判別し，ハザードマップの作成を行う。 
表 $-1 \quad$ 斜面崩壊のアイテムのカテゴリー化

\begin{tabular}{|c|c|c|}
\hline アイテム & 分類 & カテゴリー \\
\hline \multirow{2}{*}{ 起伏量 } & $0-5$ & 1 \\
(m) & $5-10$ & 2 \\
& $10-20$ & 3 \\
& $>20$ & 4 \\
\hline \multirow{3}{*}{ 傾斜角 } & $0-15$ & 1 \\
(度) & $15-30$ & 2 \\
& $30-40$ & 3 \\
& $40-90$ & 4 \\
\hline \multirow{4}{*}{ 地質 } & 砂岩泥岩互層 & 1 \\
& 安山岩 & 2 \\
& 低地堆積物 & 3 \\
& 火山岩 & 4 \\
\hline \multirow{5}{*}{ 土地利用 } & 人工物 & 1 \\
& 広葉樹 & 2 \\
& 針葉樹 & 3 \\
& 田畑 & 4 \\
& 竹林 & 5 \\
\hline
\end{tabular}

\begin{tabular}{|c|c|c|c|c|c|}
\hline \multirow[b]{2}{*}{ メッシュID } & \multicolumn{3}{|c|}{ 素因のカテゴリー } & \multicolumn{2}{|c|}{ 外的基準 } \\
\hline & 起伏量 & 傾斜角 & 地質土 & 土地利用 & 崩壊 \\
\hline 1 & 1 & 2 & 1 & 3 & 0 \\
\hline 2 & 1 & 3 & 2 & 3 & 0 \\
\hline 3 & 1 & 4 & 1 & 1 & 1 \\
\hline 4 & 2 & 4 & 1 & 3 & 1 \\
\hline 5 & 3 & 4 & 1 & 2 & 0 \\
\hline 6 & 2 & 4 & 2 & 2 & 0 \\
\hline 7 & 4 & 3 & 3 & 2 & 0 \\
\hline 8 & 4 & 3 & 4 & 2 & 1 \\
\hline 9 & 4 & 4 & 2 & 4 & 1 \\
\hline 10 & 3 & 4 & 1 & 4 & 1 \\
\hline 11 & 4 & 1 & 3 & 1 & 0 \\
\hline$\cdots$ & . & . & . & . & . \\
\hline . & . & . & .. & .. & . \\
\hline
\end{tabular}

図-3＼cjkstart崩壊影響素因と外的基準のマトリックス

この手法では, 解析対象範囲をメッシュで区切り, 各メッ シュの斜面崩壊の有無を外的基準(目的関数)とし，これと の関係を調べたい斜面崩壊の各要因アイテム(素因)の目的 関数への反応パターンから各メッシュの斜面崩壊の危険度 を判定する．解析の手順を以下に述べる.

各要因アイテムを更に分類して，カテゴリーに分類する. 表-1のように，各アイテムを分類(例えば，起伏量は 4 分 類，傾斜角度は 4 分類等)することで，定量的な素因(起伏 量等)と定性的な素因(地質等)をすべてカテゴリーに变換 する．崩壊の有無についても分類(例えば崩壊あり0で, なし 1 で分類する)し，各メッシュのカテゴリーと崩壊の 有無から構成されるマトリックスを作成する，図-3には崩 壊影響アイテムのカテゴリーと崩壊の有無のマトリックス を示す.

以上のマトリックスを数量化理論解析プログラムで読み 込み，統計解析を行い，各カテゴリ一のスコアが得られる。 表-2の右 2 列目にカテゴリースコアの例を示す．このカテ ゴリースコアは, 崩壊発生の危険度を表現するあのであり, 数值が大きいほうが斜面崩壊の危険度が高いことを意味す る. それぞれの数值を正規化し $(0 \sim 1$ の間の数值にする), 一つのメッシュの中の各カテゴリースコアの正規化後の值
表-2 カテゴリースコアから変換した評価点数の例

\begin{tabular}{|c|c|c|c|c|}
\hline アイテム & 分類 & カテゴリー & カテゴリースコア & 証価点数 \\
\hline \multirow{2}{*}{ 起伏量 } & $0-5$ & 1 & 0.0124 & 0.08 \\
(m) & $5-10$ & 2 & 0.0223 & 0.15 \\
& $10-20$ & 3 & 1.2363 & 8.32 \\
& $>20$ & 4 & 0.8654 & 5.82 \\
\hline \multirow{3}{*}{ 傾斜角 } & $0-15$ & 1 & 0.1341 & 0.90 \\
(度) & $15-30$ & 2 & 0.3453 & 2.32 \\
& $30-40$ & 3 & 2.9821 & 20.00 \\
& $40-90$ & 4 & 0.3842 & 2.59 \\
\hline \multirow{4}{*}{ 地質 } & 砂岩泥岩互層 & 1 & 0.0932 & 0.63 \\
& 安山岩 & 2 & 0.231 & 1.55 \\
& 低地堆積物 & 3 & 1.1213 & 7.55 \\
& 火山岩 & 4 & 0.2321 & 1.56 \\
\hline & 人工物 & 1 & 0.0325 & 0.22 \\
土地利用 & 広葉樹 & 2 & 0.1342 & 0.90 \\
& 針葉樹 & 3 & 0.1453 & 0.98 \\
& 田㚼 & 4 & 0.0431 & 0.29 \\
& 竹林 & 5 & 0.4522 & 3.04 \\
\hline
\end{tabular}

を合計し，その合計值でメッシュの崩壊発生危険度を代表 する ${ }^{11)}$. 一般的に合計数值が小さいため, 下記の式(1)で 正規化の後の值を拡大(例えば20倍)し, 評価点数とし, 合 計点数を計算する。表-2の最右の列には式(1)で計算した 評価点数の例を示す.

$$
\text { 評価点数 }=\frac{\mid \text { カテゴリースコア }-S_{\min } \mid}{\left|S_{\max }-S_{\min }\right|} \times 20
$$

ここに, $S_{\max }$ はすべてのカテゴリーのスコアの最大值で, $S_{\min }$ はその最小値を意味する.

数量化理論解析は, 各素因のカテゴリー化をすることで, 経験的な数值を一定の基準で定量化することができるのが 大きな特徴である. 加えて, 一つのアイテム内における力 テゴリースコアのばらつきの大きさを示すレンジにより， 要因の影響の大きさを評価できる利点むある。しかしなが ら，このような統計的な方法の実用化においてもっとも重 要なポイントは, いかに効率的に高い精度の崩壊履歴と素 因の空間分布值を得るかという点にある.

斜面崩壊の危険度評価対象範囲が広い場合, 考慮すべき 素因も多いため, 従来の方法では数量化理論解析の実用化 に大きな課題が残されている。

\section{3 斜面崩壊の数量化理論解析のための素因}

斜面崩壊に影響する素因は種々考えられるが，下記の素 因が斜面崩壊評価を行う場合によく使用されてい $3^{1,2), 4), 77,11)}$

\section{（1）傾斜角度}

傾斜角度は，斜面の最急勾配方向に抏いて斜面と水平面 の間の角度で, 斜面崩壊に極めて重要な指標で, その空間 分布の把握が必要不可欠である。

\section{（2）傾斜方向}

傾斜方向は，斜面の最急勾配方向の矢印を平面に投影し たものの方位角である，斜面の向きにより降雨量，日照量 や気温に違いがあり，これが斜面崩壊に影響を与えると考 えられる。

\section{（3）起伏量}

起伏量は, 一定範囲内(例えば一つのメッシュ範囲)にお ける地形標高の最大と最小の差を意味し, 地形の凹凸の量 
を反映する指標である。

\section{（4）横断形状}

地形の断面を作り，その形状の凹，平坦，凸の区分拉よ びその量を意味する．地形が平坦な場合は斜面崩壊の危険 性が低く, 凹と凸の場合は斜面の崩壊のパターンも違うと 考える.

\section{（5）集水面積}

ある地域に水が流れてくる周辺地域の面積を意味する。 降雨の場合は，地形上ある場所に周辺から水が流れるかと か周辺地形の標高や傾斜方向で決定される. 周辺から傾斜 集水しやすい場所は，崩壊の危険性が高いと考える.

\section{（6）土地利用}

土地利用の形態によって斜面崩壊にも影響があると考え られる。例えば，竹林地域は地下水が豊富で根が浅いため， 表層崩壊の発生しやすい場所とされている.

\section{（7）地質}

地質は地盤の力学特性や層理・節理などの弱面の形成に 関連するため，斜面崩壊にも影響する.

\section{（8）崩壊履歴}

過去の崩壊履歴筒所の分布図は数量化理論解析の外的評 価基準として極めて重要なデータである，その輪郭の分布 の抽出にはいくつかの方法がある(例えば, 現地調査, 写 真判読, 衛星データの解析等).

上記以外の斜面崩壊影響素因も考えられるが，本研究で は，以上を代表的なむのとして使用し，GISによるデー夕 の作成方法を提案し, 現場への応用により実証を行う.

\subsection{GISを用いた数量化理論解析の効率化の提案}

GISの高い空間デー夕処理能力を利用し，数量化理論解 析に必要な影響素因の空間分布を作成し，数量化理論の解 析結果をGISに取り込みハザードマップ作成を行う効率化 したシステムを図-4のように提案する.

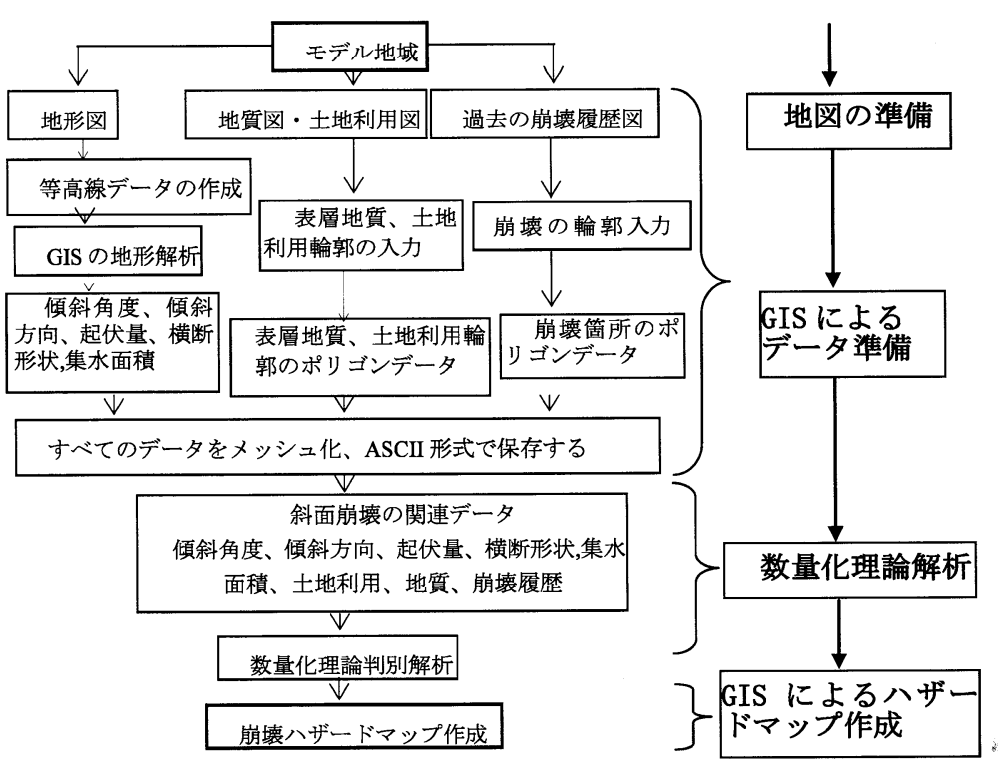

図-4
提案する方法は, 大きく以下の三つのステップから構成 される.

（1）地図の準備

さまざまな斜面崩壊に関連する地図を収集し入力の準備 を行う。地図のスケールと精度に留意する必要がある。

\section{（2）GISによるデー夕準備}

これは本研究で提案するGISによる数量化理論解析の中 でも最も重要なステップで，具体的な処理方法については 2.5で詳細に述べる. GISで準備したデー夕をASCIIファイ ルとして保存し，数量化理論解析に提供する.

\section{(3) 数量化理論解析}

GISで用意されたデー夕を数量化理論解析プログラムで 読み込み, 判別解析を行う。

（4） GISによるハザードマップの作成

数量化理論解析から得られた各カテゴリースコアを評価 点数に変換し，評価点の合計值を分類し，ハザードマップ の作成を行う。

\subsection{GISによるデータの準備}

2.5.1 GISデータ入力

入力データとして, 地形図, 土地利用図, 地質図, 崩壊 履歴図等がある。デジタイザを使用して入力を行う方法も あるが，この場合非常に時間が掛かり効率が悪いため, 本 研究では, 下記のような方法で入力することを提案する.

(1) 地図のスキャン

収集した地図は， $\mathrm{A} 4$ ～B1 サイズのものがあり，これ らをカラースキャンして，画像として保存する.

(2) 画像の座標補正

GISソフトで画像を読み込み，座標補正を行う。座標系 に関しては，一般的に $1 / 5,000$ 以下の大縮尺の地図は平面 直角座標系が多いが，それ以上の小縮尺の地図はUTMや 緯度経度がよく使用される。座標補正の方法はGISソフト

によって多少異なるが，基本的にGCP(Ground Control Point)あるいは地网の四隅の网郭の座標を

表-3ＧISによるデータの入力

\begin{tabular}{|c|c|c|}
\hline 素因 & $\begin{array}{c}\text { GISデータ } \\
\text { の形式 }\end{array}$ & 属性の内容 \\
\hline 地形 & Polyline & 等高線の標高 \\
\hline 地質 & Polygon & $\begin{array}{l}\text { 地質区分コード番号 } \\
\text { 地質種類に応じて順番に } \\
\text { コード番号で記入 }\end{array}$ \\
\hline 土地利用 & Polygon & $\begin{array}{l}\text { 土地利用コード番号 } \\
\text { 土地利用種類に応じて順 } \\
\text { 番にコード番号で記入 }\end{array}$ \\
\hline 崩壊履歴 & Polygon & $\begin{array}{l}\text { コード番号 } \\
\text { 崩壊あり : } 1 \\
\text { 崩壊なし : } 0\end{array}$ \\
\hline
\end{tabular}


利用して補正を行う。

\section{(3) GISデータの入力}

座標補正した地図画像を基に, GISの自動追跡と半自動 追跡の方法(いわゆるラスターベクター変換手法)で効率的 に地図のデジタル化を行う。このようなGIS手法を用いれ ば，従来の手法では数日間掛かる入力作業を数時間で完了 することが可能である，地形図には，等高線および標高值 をポリライン(Polyline)データとして入力する.とくに急 な崖地の場合を反映する場合はBreaklineを活用すること が必要である. 地質, 土地利用, 崩壊履歴は, ポリゴン (Polygon) データとして, 輪郭の分布と属性(地質区分と 土地利用)を入力する(表-3).

\subsection{2 標準メッシュの作成}

標準メッシュとは, 数量化理論解析を行う地域を分割す る基本的なメッシュである。メッシュのサイズは，研究対 象地域で収集したデータの精度, 崩壊の規模等を総合的に 考慮して決定すべきである.メッシュの作成は，一般的に GISの作成ツールがあり，範囲を設定すれば，簡単に対象 地域をカバーするメッシュを作成することができ，各メッ シュの番号がそのメッシュの属性とされる.

\subsection{3 地形解析}

\section{(1) TINモデルの構築}

入力した地形等高線を使用し，TINデー夕を作成する。 TINとは，不整三角網(Triangulated Irregular Network) と呼ばれ，ランダムに配置された点を一番近い 3 点で結び, 三角形で地表面の形状を表現するデータモデルである(図5)，等高線によるTINの作成には，線を一定間隔で点に变 換してTINを作成する方法と, 直接線上の変化点(ノード) を使用して作成する方法がある.

\section{(2) デー夕変換}

地形のTINモデルからラスター形式に変換することで, セル形式の地形ラスターデータが得られる.

\section{(3) 地形解析}

地形のラスターデータを使用して, GISの一般的な地形 解析で下記のデー夕を簡単に整備することができる.

(1)標高分布

(2)傾斜角度

(3)傾斜方向

これらのデータはラスターデータの形式で得られ，セル のすべての情報(座標位置, 属性)をデジタルデータとして

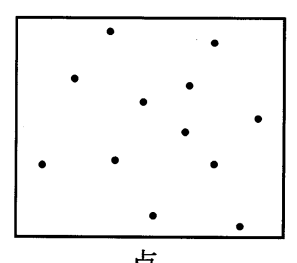

点

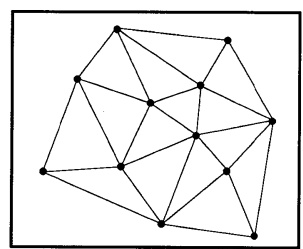

面 (TIN)
図-5＼cjkstart地形のTINモデルの構築
ASCIIの形式でGISから外部へ出力することが可能である.

\subsection{4 地形起伏量}

一般的に数量化理論解析のための標準メッシュのサイズ を地形ラスターデータのセルよりむ大きく設定するので, 一つのメッシュの中に多数の地形セルが含まれる．このメッ シュに含まれる地形セルの最大值と最小值の差がこのメッ シュの地形起伏量に相当する. GISのラスターデー夕解析 機能の中のゾーン統計機能(Zonal Statistics)を使用すれ ば，簡単にメッシュごとの起伏量の数值が得られる. 図-6 に示されるように，Zonal Statisticsという計算では，地 形標高のラスターデータに対して, 統計用のメッシュを使 用し，そのメッシュの範囲に含まれる多数の地形セル(図 の場合は 9 個のセル)の值の統計計算を行い, 得られた統 計值をそのメッシュに属性として与える. 統計值としては, 最小值 (Min), 最大值 (Max), 平均值 (Mean), レンジ (Range), 偏差值(STD), 多数值 (Majority)が得られる. この中の, レンジという統計值はセル值の最大と最小の差 で，起伏量に相当する值である，従来の手法による起伏量 の計算では，専用のプログラムを作成して処理をする必要 があったが, GISの機能を利用すれば，メッシュデータと ラスターデータ間の簡単な演算で効率的にデータの準備が できる.

\subsection{5 横断形状}

横断形状は, 図-7に示されるように, 地形セル (中心 9 番)の周りのセルの標高の平均值とその中心セルの標高值 との差で現す(式(2)).

$$
\text { 地形セルの横断形状值 }\left(P_{9}\right)=\left[\frac{\sum_{i=1}^{8} h_{i}}{8}\right]-h_{9}
$$

ラスターデータの近隣解析 (Neighborhood Analysis) 機能を使用すれば，横断形状の值の分布が得られる．GIS の近隣解析では, 地形の標高ラスターデータを対象とし, 図-8(1)に示されるように，任意のセル(Processing cell)

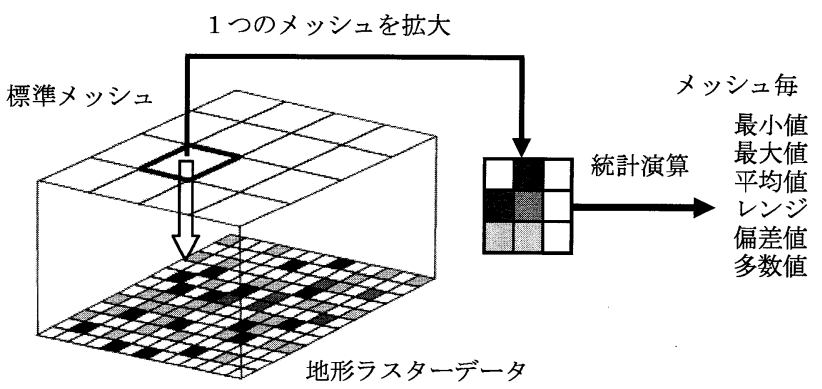

図-6ＧISのゾーン統計による起伏量の取得

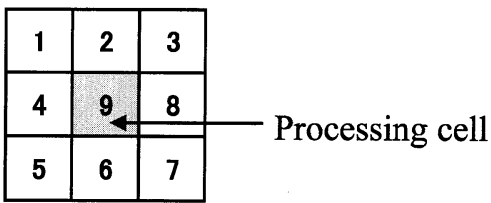

図-7＼cjkstart横断形状の計算ための地形セル図 
の周辺八つのセルの標高值の平均值を計算し，そのセルの 属性として与え, 新しいラスターデータ (平均值ラスター) が作成される(図-8(2)). さらに，この平均值ラスターデー 夕と元の地形標高ラスターデータとの引き算を行うことで (図-8(3)), 横断形状の值が得られる.

\subsection{6 集水面積}

集水面積は一つの地形セルに水が流れてくる周辺セルの 数を意味する. GISのラスターデータを用い, 各セルの最 急勾配方向(水の流れの方向)を計算し，その方向および標 高を比較することで各セルの集水域を抽出し, 集水面積を 計算する ${ }^{16)}$. 本研究では，下記のアプローチでGISの空間 解析を行い, 集水面積の計算を行う.

(1) 数值地形の凹点の検出と処理(fill sink)

数值地形の中に標高の内挿による䛊差が生じる可能性が ある，例えば，地形のセルの中に標高が極めて低い孤立す

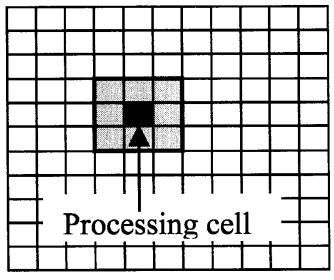

原地形ラスターA

(1) 近隣解析実施

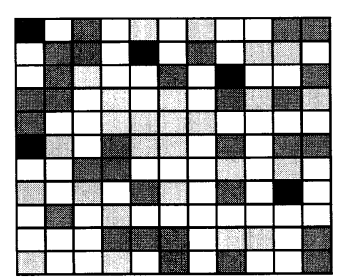

（3）引き算解析による横断形状ラスターデータ作成

図-8＼cjkstart横断形状の計算ためのGIS統計処理

\begin{tabular}{|l|l|l|l|l|l|l|}
\hline 49 & 67 & 56 & 49 & 46 & 50 & 47 \\
\hline 47 & 53 & 44 & 37 & 38 & 48 & 40 \\
\hline 50 & 58 & 55 & 22 & 31 & 24 & 23 \\
\hline 42 & 61 & 47 & 21 & 16 & 19 & 18 \\
\hline 36 & 53 & 34 & 12 & 11 & 12 & 12 \\
\hline 38 & 39 & 30 & 12 & 10 & 9 & 13 \\
\hline 50 & 52 & 33 & 12 & 9 & 7 & 15 \\
\hline
\end{tabular}

図-9 標高ラスターデータの例(数值は標高, 単位：m)

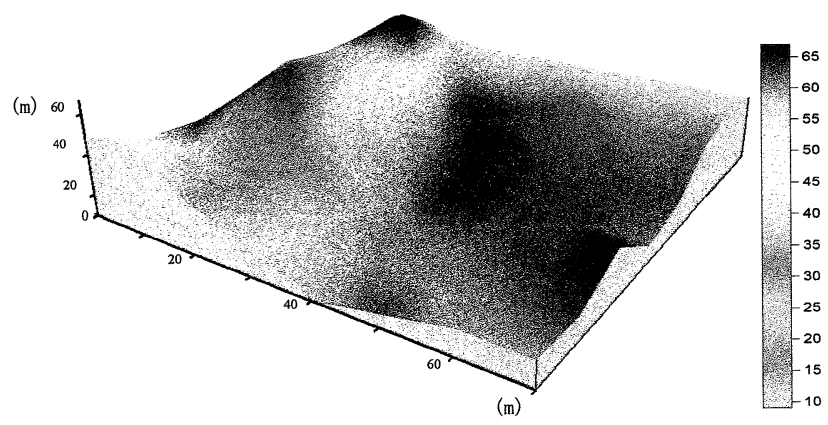

図-10＼cjkstart標高の 3D図

るセルが存在する場合がある．このようなセルは集水域の 抽出に影響するため, 当該セルを見つけ出して, 周辺セル の標高の平均值を与えなおす操作が必要である．図-9には 標高ラスターデータの例を, 図-10にはその標高ラスター データの 3D図を示す.

\section{（2）流れの方向の計算(flow direction)}

あるセルの標高に対して周辺八つのセルの標高との差沶 よび中心点の距離で傾斜角度を計算し，その中の最急勾配 方向を確定する ${ }^{6)}$. 図-11には各セルの最急勾配方向の例 を示す。外縁部セルの勾配計算には外側のセルの標高を参 考にしたため，その最急勾配方向の表示を省略した：GIS デー夕処理の便を考え, 最急勾配方向を数值で示す必要が ある. 図-12には一つのセルに対して流れる八つの方向を 代表する值を示す，例えば，南方向を 4 ，北方向を 64 とす る。図-13は図-11で示した流れ方向を，図-12に示した流 れ方向值で示した例である。

（3）流れの集計(Flow accumulation)

一つのセルに周囲から水が流れてくるセルの数を集計す る。これは流れの方向值を利用し, 流れてくる可能性のあ るセル(集水セル)の数をカウントする.すべてのセルに対 してこのカウントを行い, カウントした值をそれぞれのセ ルに与える. 図-14には計算した集水セルの数の例を示す. その見方の例として, 図の 3 行 4 列目のセル值は 5 であり, 図-11を参考に見ると，そのセルの周囲から五つのセル(図14の中に灰色で示されたセル)の水が流れてくることがわ かる.

以上のような計算が一部のGISソフトでは標準的機能と なっている．地形ラスターデータがあればこの計算を実行 することにより，各セルの集水面積を簡単に得ることがで きる. 従来の手法では集水面積の計算は大变煩雑な処理を 要する作業であったが，GISの機能を活用した計算では作

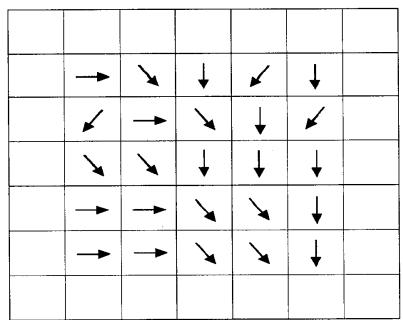

図-11＼cjkstart各セルでの最急勾配方向

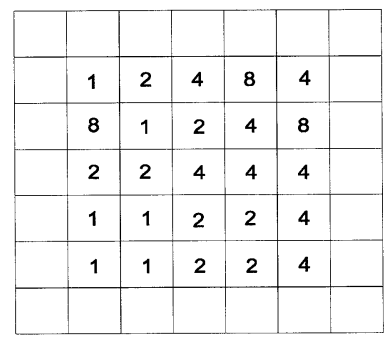

図-13 方向値で表した最急勾配

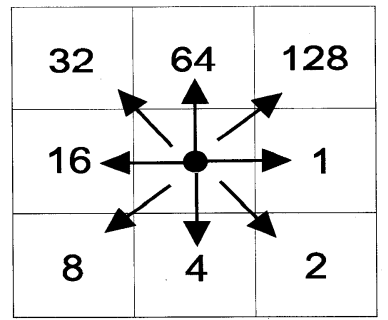

図-12 流れ方向値の設定

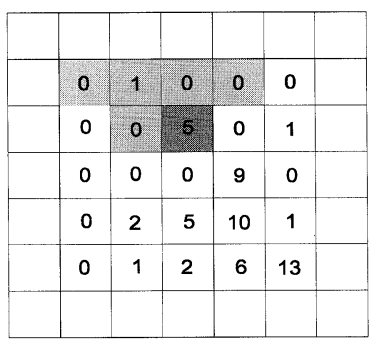

図-14 流れの集計計算 


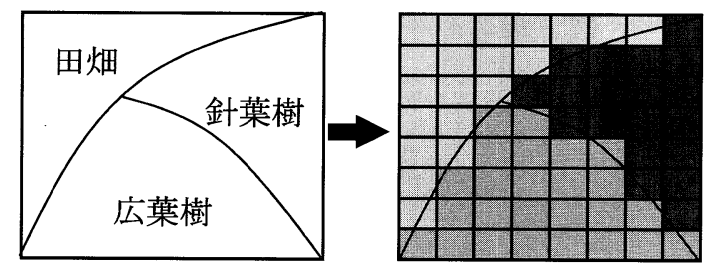

図-15 土地利用, 地質のデータのラスター化

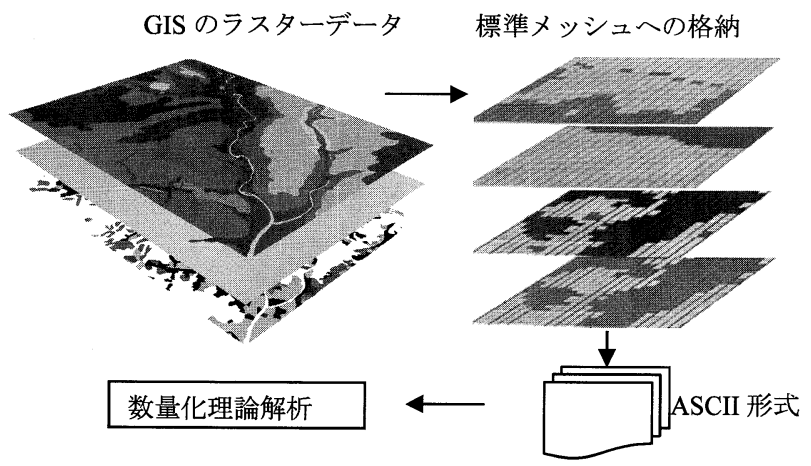

図-16 GISデータの標準メッシュへの格納の概念図

業時間を大幅に短縮することができる.

\subsection{7 土地利用, 地質と崩壊履歴}

土地利用, 地質および崩壊履歴のデー夕は，GISにポリ ゴンデータとして入力するが，標準メッシュにデータを格 納するために，図-15に示したようにこれらのデータをラ スターデータの形式に变換する.

\subsection{GISによるデータの標準メッシュへの格納}

以上のステップで作成された崩壊素因と崩壊履歴のGIS デー夕を標準メッシュへ格納する必要がある(図-16)，作 成されたGISデー夕はすべてラスターデータの形式である ため，2.5の起伏量データの作成で提案したゾーン統計方 法(図-6)を使用して統計姏理を行うことにより，標準メッ シュに各種類のラスターデータを格納する。

ラスターデータの統計処理は下記のように行う。

A. 傾斜角度 ゾーン統計の平均值を使用する。

B. 横断形状 ゾーン統計の平均值を使用する。

C. 地形起伏量 2.5 に説明した方法でデー夕を準備する.

D. 集水面積 メッシュサイズでの地形ラスターデー夕を 作成し，それを使用して集水面積の計算を行う。得られ た集水面積のラスターデータのセルサイズはメッシュサ イズと一致するので，ゾーン統計を行うと，集水面積う スターセルの值をそのままメッシュに格納することにな る.

E. 土地利用・地質 一つのメッシュに複数の土地利用が 含まれる場合は, ゾーン統計の多数值を使用すれば面積 の多い土地利用と地質区分をそのメッシュに与えること ができる．図-17に示すように，一つのメッシュに 3 種 類の土地利用があり，土地利用のラスターのセルにあ 3 種類の土地利用コード番号(真ん中の図)が含まれる場合 についてメッシュのゾーン統計を行うと, 多数值は 3 ,

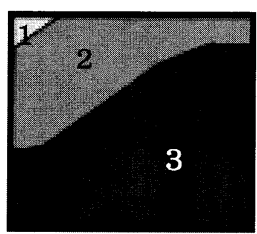

複数の土地利用

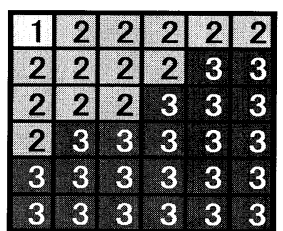

土地利用ラスター

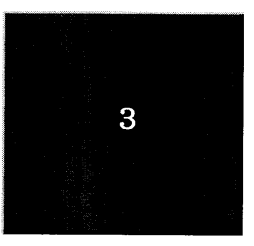

多数值での土地利用

図-17 複数の土地利用の場合のメッシュ

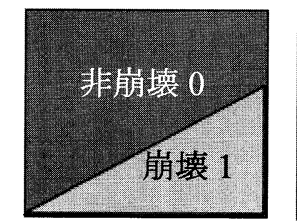

メッシュの一部が崩壊

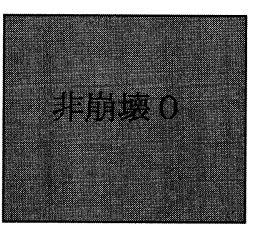

多数值使用

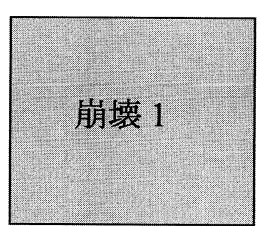

最大值使用
図-18 崩壊履歴のメッシュ対応処理の方法

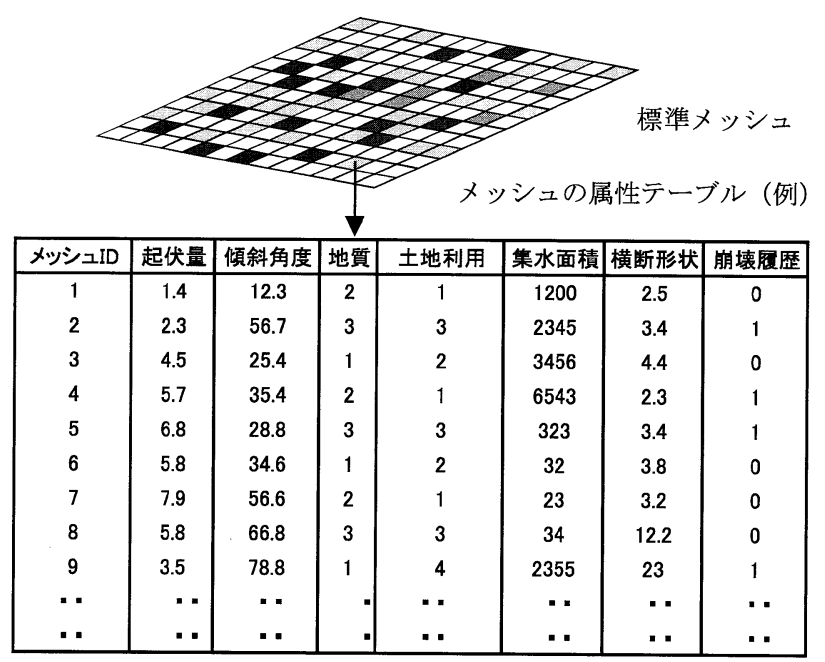

図-19 GISの標準メッシュに格納された属性データ

最小値は 1 , 最大值は 3 , 平均値は 2.5 となる. 多数值を 使用すれば，面積の最大の土地利用番号をそのメッシ」 に与えることになる。

F. 崩壊履歴 一つのメッシュの全範囲が崩壊区域である 場合はそのメッシュが崩壊メッシュとして問題がないが, メッシュの一部に崩壊範囲が含まれる場合 (図-18の左図) は，そのメッシュを崩壊メッシュか非崩壊メッシュに判 定する必要があり，その処理には二つの方法がある。図18に示すように, ゾーン統計の最大值を使用する場合は 崩壊メッシュになり(崩壊が 1 , 非崩壊が 0 とする場合), 多数值を使用すれば，崩壊の面積がそのメッシュの半分 以上でない場合は非崩壊メッシュとなる。

以上の作業によって，ポリゴンデータである標準メッシュ にすべての素因の值が属性として格納される(図-19)。こ の属性デー夕は多くのGISソフトではテーブルの形式で表 示され，外部に保存することができる.

\section{7 数量化理論解析とハザードマップの作成}

以上のGISの解析操作で数量化理論解析に必要なデー夕 の準備ができる．標準メッシュの属性データをGISから外 部にエキスポートする。基本的にTXT, EXCELあるいは 
DBFの形式になる。このようなデー夕はEXCELで整理す ることにより, ほとんよ゙の数量化理論の解析プログラムに 読み込むことができる。このデータを用いて 2.2 に説明し た数量化理論解析を実行すれば，それぞれのアイテムのカ テゴリースコアと評価点数が得られる．EXCELあるいは プログラムで標準メッシュの属性テーブルを読み込み, 各 メッシュの各カテゴリーの評価点数を合計し, その合計值 を分類し，GIS上の標準メッシュに表示すれば危険度ラン ク分けをした崩壊危険性ハザードマップができる。このよ うに, GISデータの属性テーブルと図形データがリンクさ れているため, 属性テーブルの操作を行うことで, 八ザー ドマップが簡単に作成できる。 そのため, 従来の数量化解 析およびハザードマップ作成手法に比べると大幅な省力化 が可能となる.

\section{3. 適用 例}

実証モデルを熊本県水俣市集地区 (面積 $=17 \mathrm{~km}^{2}$ ) とし (図-20), 提案した方法でデータ入力および解析を行った。

\section{1 モデル地域の地質および斜面災害状況}

この地域では過去に降雨による多くの斜面崩壊が発生し ており，とくに平成15年 7 月 20 日に発生した豪雨災害に伴 う斜面崩壊による土石流災害は, 死者15名, 住宅の全半壊 15棟という甚大な被害が生じている。

地域の地質は, 最下部に基盤岩である泥岩が主体として, 砂岩頁岩互層(白亜系四万十累層群)が分布する.この基盤 岩の上に風化した安山岩質の磁を含む凝灰角碟岩が分布し, 最上部の尾根沿いに安山岩が分布している. 平成 15 年 7 月 に発生した土石流のきっかけとなった大規模な崩壊は,こ の安山岩之凝灰角礫岩が分布する斜面で発生している。土 石流は流域中ほどの右岸斜面標高 $410 \mathrm{~m}$ 付近で発生した大 規模な崩壊が土石流化し, 約 $1.5 \mathrm{~km}$ 流下して, 集地区で氾 濫堆積したものである。崩壊した土砂量は約 $43,000 \mathrm{~m}^{3}$, 崩 壊残土量は約 $12,000 \mathrm{~m}^{3}$ と推定されている。この朋壊土砂量 に加えて, 渓床や渓岸から浸食した約 $60,000 \mathrm{~m}^{3}$ の土砂量が 土石流として流下し, 災害を生じさせたものである ${ }^{17)}$.

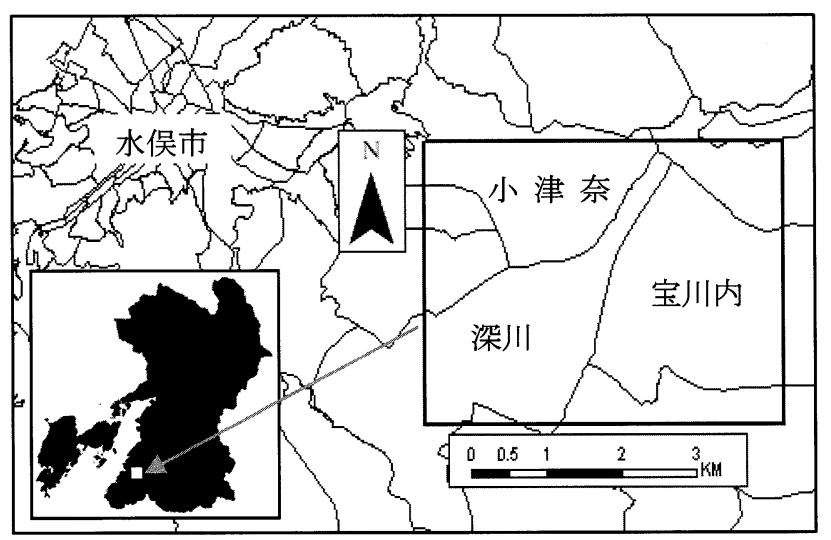

図-20 実証モデル地域(熊本県水俣市集地区)

\section{2 データの入力}

当該地域の地形図(縮尺 $=1 / 2,500)$, 土地利用図(縮尺 $=$ $1 / 50,000$, 熊本県企画振興部土地資源対策課), 地質図(縮 尺 $=1 / 50,000$, 熊本県企画振興部土地資源対策課), 崩壊 履歴図（縮尺 $=1 / 25,000 ）$ を収集し，画像をスキャンしGIS に取り込んだ。崩壊履歴図は水俣市芦北振興局が過去の斜 面崩壊調査結果に基づいて作成したものである. 入力した 地形図の等高線からGISのTINモデルを構築し, 地形標高,
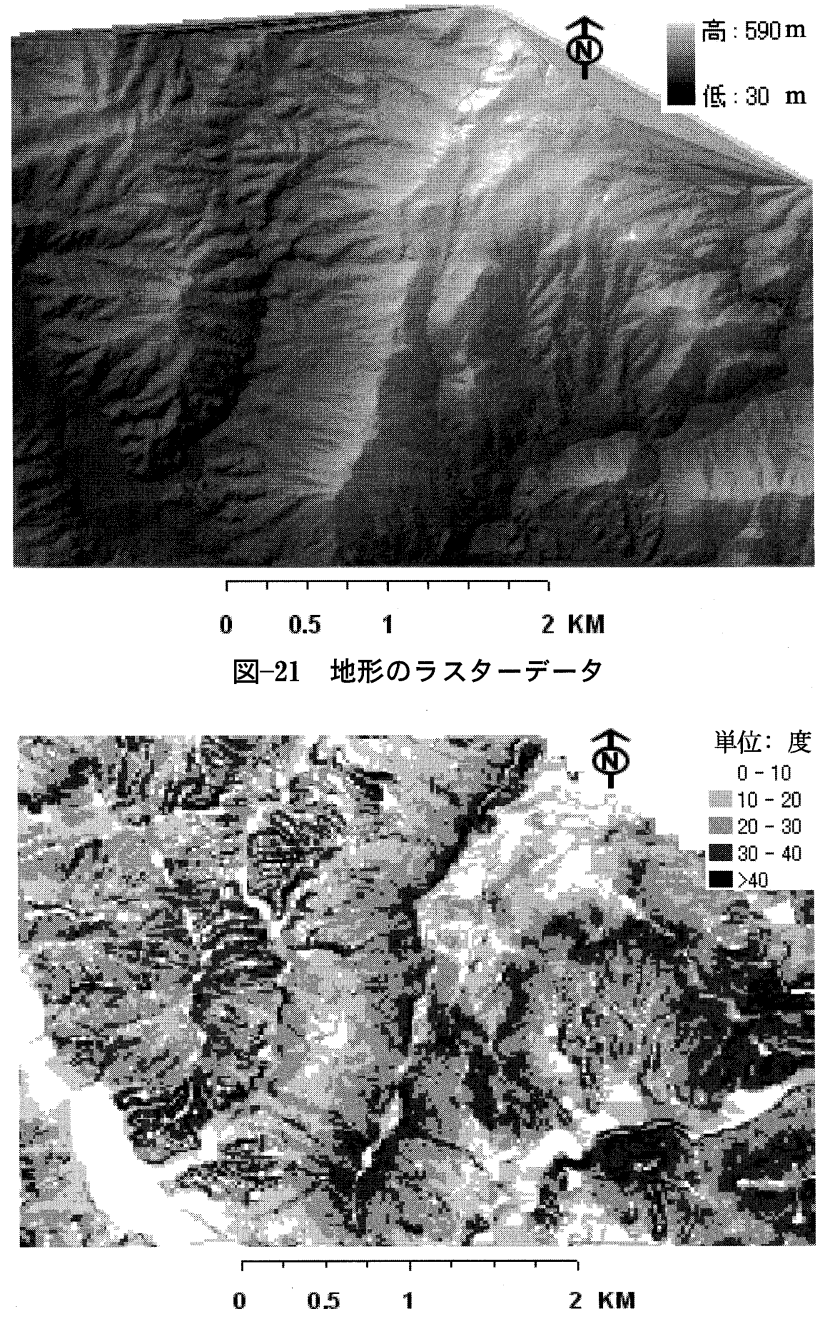

図-22 傾斜角度のメッシュデータ

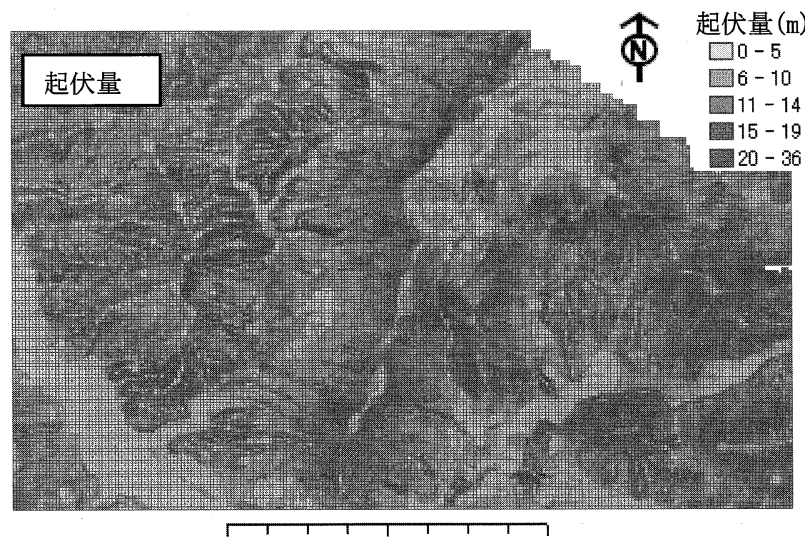

$\begin{array}{lll}0 & 0.5 & 1\end{array}$

$2 \mathrm{KM}$

図-23 起伏量のメッシュデータ $(\mathrm{m})$ 
傾斜角度，傾斜方向をラスターデータとして作成した。図一 21 に標高ラスターを示す. 地形横断形状, 地質, 土地利用, 起伏量, 集水面積のGISデー夕あ入力・整理した。過去の 崩壊履歴の分析により ${ }^{9)}$ 11), 過去の斜面崩壊の形状と規模 を全体的に見ると, 辺長が $20 \mathrm{~m}$ 以上の四角形に相当する場

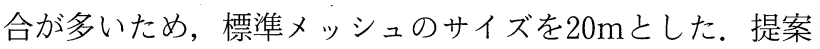
したデータの標準メッシュ格納方法により，上記のデー夕 のメッシュへの格納を行った．図-22〜26は標準メッシュ

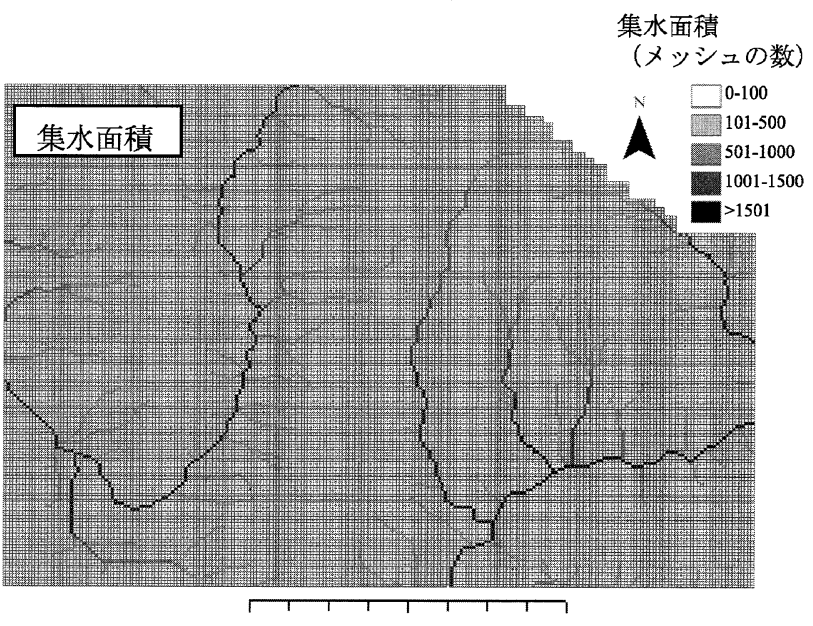

$\begin{array}{llll}0 & 0.5 & 1 & 2 \mathrm{KM}\end{array}$

図-24 集水面積のメッシュデータ
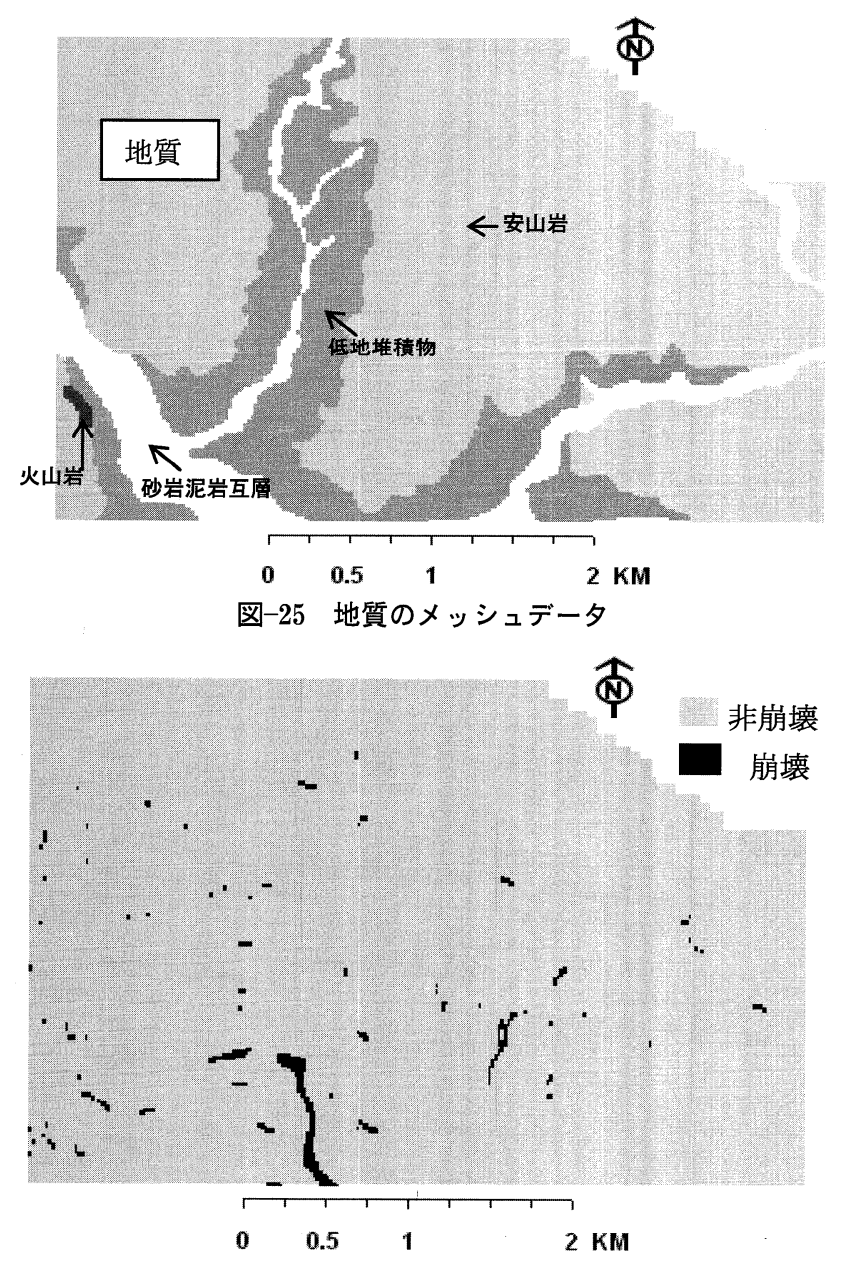

図-26 崩壊履歴のメッシュデータ
で表示された素因の例と崩壊履歴の分布図である.

\section{3 数量化理論解析とハザードマップ作成}

以上の標準メッシュに格納した各素因の属性テーブルを ASCIIの形式で保存し, MS Excelで分類, 整理した。土 表-4 数量化 II 類判別解析結果

\begin{tabular}{|c|c|c|}
\hline $\begin{array}{c}\text { 実際な崩壊メッシュ数 } \\
360 \\
\end{array}$ & $\begin{array}{c}\text { 崩壊と判定したメッシュ数 } \\
215 \\
\end{array}$ & $\begin{array}{c}\text { 非崩壊と判定したメッシュュ数 } \\
145\end{array}$ \\
\hline \multicolumn{3}{|c|}{$\begin{array}{c}\text { 判定的中率=215/360 } \\
=60 \%\end{array}$} \\
\hline $\begin{array}{c}\text { 実際な非崩壊メッシュ数 } \\
37981\end{array}$ & $\begin{array}{c}\text { 非崩壊と判定したメッシュ数 } \\
25960\end{array}$ & $\begin{array}{c}\text { 崩壊と判定したメッシュ数 } \\
12021\end{array}$ \\
\hline \multicolumn{3}{|c|}{$\begin{array}{c}\text { 判定的中率 } \\
=25960 / 37981=68 \%\end{array}$} \\
\hline
\end{tabular}

表-5カテゴリースコアと得点計算結果

\begin{tabular}{|c|c|c|c|c|c|}
\hline アイテム & 分類 & カテゴリー & カテゴリースコア & 得点 & $\begin{array}{c}\text { 出現頻度 } \\
\text { (メッシュ数) }\end{array}$ \\
\hline \multirow{4}{*}{$\begin{array}{l}\text { 起伏量 } \\
(\mathrm{m})\end{array}$} & $0 \sim 1$ & 1 & -0.2753 & 8.48 & 807 \\
\hline & $1 \sim 5$ & 2 & -0.1286 & 9.12 & 4265 \\
\hline & $5 \sim 9$ & 3 & 0.2361 & 10.72 & 10784 \\
\hline & $10 \sim$ & 4 & -0.0789 & 9.34 & 22485 \\
\hline \multirow{4}{*}{$\begin{array}{r}\text { 傾斜角 } \\
\text { (度) }\end{array}$} & $0-20$ & 1 & -0.4311 & 7.79 & 13102 \\
\hline & $20-30$ & 2 & -0.5484 & 7.28 & 13537 \\
\hline & $30-40$ & 3 & 0.0798 & 10.04 & 9975 \\
\hline & $>40$ & 4 & 0.1164 & 10.20 & 1727 \\
\hline \multirow[t]{4}{*}{ 地質 } & 砂岩泥岩互層 & 1 & 1. 3552 & 15.64 & 3774 \\
\hline & 安山岩 & 2 & 0.1458 & 10.33 & 26624 \\
\hline & 低地堆積物 & 3 & -1.8899 & 1.38 & 7877 \\
\hline & 火山岩 & 4 & -0.2228 & 8.71 & 66 \\
\hline \multirow[t]{8}{*}{ 土地利用 } & 田畑 & 1 & 0.0022 & \begin{tabular}{|l|}
9.69 \\
\end{tabular} & 3972 \\
\hline & 針葉樹 & 2 & 0.2594 & 10.82 & 28049 \\
\hline & 果樹園 & 3 & -1.0779 & 4.95 & 1167 \\
\hline & 広葉樹 & 4 & -1.3436 & 3.78 & 3633 \\
\hline & 竹林 & 5 & 0.2419 & 10.75 & 680 \\
\hline & 茶畑 & 6 & -1.5423 & 2.91 & 47 \\
\hline & 人工物 & 7 & -1.3862 & 3.60 & 766 \\
\hline & その他 & 10 & -2.2047 & 0.00 & 74 \\
\hline \multirow[t]{3}{*}{ 横断形状 } & 凸 & 1 & -0.7410 & 6.43 & 4344 \\
\hline & 平 & 2 & 0.1584 & 10.38 & 29671 \\
\hline & 凹 & 3 & -0.3422 & 8.18 & 4236 \\
\hline 集水面積 & $0 \sim 99$ & 1 & 0.0327 & \begin{tabular}{|l|}
9.83 \\
\end{tabular} & 36103 \\
\hline \multirow[t]{4}{*}{ (メッシュ数) } & $100 \sim 499$ & 2 & -0.8147 & 6.11 & 1440 \\
\hline & $500 \sim 999$ & 3 & -0.9211 & 5.64 & 181 \\
\hline & $1000 \sim 4999$ & 4 & -1.2066 & 4.38 & 361 \\
\hline & $5000 \sim$ & 5 & 2. 3484 & 20.00 & 254 \\
\hline
\end{tabular}

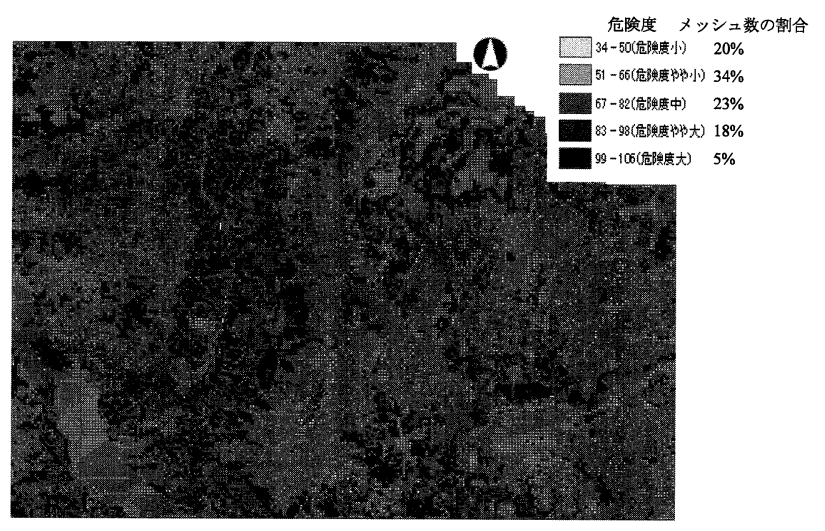

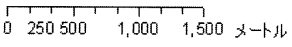

図-27 斜面崩壊ハザードマップ 
地利用は 8 分類, 地質は 4 分類, 傾斜角度は 4 分類, 横断 形状は 3 分類, 集水面積は 5 分類で各アイテムのカテゴリー

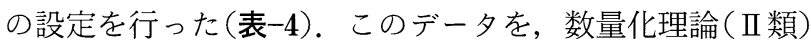
解析機能を有するソフトであるSPSSに読み込み, 崩壊判 別解析を行った，解析結果は下記のようになっており，的 中率は $60 \%$ であった(表-4). 的中率とは，「崩壊」と判別 したメッシュの数(215個) と実際に崩壊したメッシュの数 (360個)との割り算である. 斜面崩壊素因の分類などの試 行錯誤の調整によりこの的中率の更なる改善ができる.

表-5には, 計算した各アイテムのカテゴリースコアを示 す。得点は式(1)で各カテゴリースコアを変換したもので ある.さらに, 各メッシュで各カテゴリーの得点の合計を 15 点ずつ 5 分類して, 崩壊危険度の小, やや小, 中, やや 大，大の 5 等級をつけ，GISでのハザードマップを作成し た(図-27). 全体の崩壊判定の的中率は60\%となっている ことから, 計算の精度はかなり満足できるむのと考える.

\section{4 提案した方法の効率と精度の検証}

本研究では, 収集したアナログの原図を使用し, 地図の デジタイズからハザードマップの作成までの各ステップに 必要な作業時間を計測・確認し, 従来の方法と比べること により本手法の効率性の検証を行った．表-6にはその検証 比較結果を示す (両方とも熟練技術者が行ったと想定した 場合のおよその作業時間である).

水俣市の集地区のデー夕についてまとめた表-6によると， 従来の方法で約 1 か月掛かっていた作業は, 本提案のGIS を活用した方法を使用することにより約 $1 / 10$ の時間で完 成できることがわかった。 また, 従来の方法では, 完成し た作業の精度確認がプログラムで計算をしないと確認でき なかったため, かなりの時間を必要としていた. 一方, 提 案した方法ではすべてのデータはGISの中に保存しており, 視覚的に確認できるので, 入力したデー夕と原図をGIS上 で拡大したり移動したりすることでデータ入力精度の確認 とデー夕修正を簡単に行える。 また従来の方法では, 最初 に標準メッシュを作成し, 次にメッシュを固定したままで

表-6ハザードマップ作成の効率性の比較

\begin{tabular}{|c|c|c|}
\hline 入力 & 本提案のGIS方法 & $\begin{array}{c}\text { 従来の方法 } \\
\text { (デジタイザとプログラ } \\
\text { ムでの整理) }\end{array}$ \\
\hline 地図のスキャン & 数分間程度 & 20分程度 (座標校正) \\
\hline 地形入力(B1サイズ4枚) & 2日程度 & 2週間程度 \\
\hline 標高分布 & 2分以内 & 1日間程度 \\
\hline 傾斜角度 & 数秒程度 & 1日間程度 \\
\hline 傾斜方向 & 数秒程度 & 1日間程度 \\
\hline 起伏量 & 数秒程度 & 1日間程度 \\
\hline 横断形状 & 2分以内 & 1日間程度 \\
\hline 集水面積 & 5分程度 & 1日間程度 \\
\hline 地質分布 & 半日程度 & 3日間程度 \\
\hline 土地利用分布 & 半日程度 & 3日間程度 \\
\hline 崩壊履歴 & 半日程度 & 2日間程度 \\
\hline メッシュの格納 & 5分程度 & 3日間程度 \\
\hline ハザードマップ作成 & 5分程度 & 1～2日間程度 \\
\hline 合計 & 3日半間程度 & 34日間程度(約1ヶ) \\
\hline
\end{tabular}

解析用のデー夕の準備をしていく必要があるため, メッシュ の变更が基本的に不可である(変更すれば最初からすべて の作業をやり直す必要がある). これに対して提案の方法 では, GISデータの入力と標準メッシュへのデータ格納が 分けられているので, 標準メッシュの变更が可能である. これにより, 解析を繰り返し行うことによりハザードマッ プの精度を向上させることが可能と考える.

\section{4. ま と め}

GISを活用した数量化理論 (II 類)による斜面崩壊ハザー ドマップの作成手法の提案，および検証を行った．主な結 論は下記のとおりである.

1)GISの強力な空間データの作成・管理と解析機能を活用 し，数量化理論と結合した高度なハザードマップの作成方 法を提案した．従来の方法では非常に煩雑なデー夕準備作 業を, 本提案の方法では大幅に省力化ができる.

2)熊本県水俣市集地区をモデル地区として，データの入力 からハザードマップの作成までを提案方法で実施・検証し た結果, 効率および精度の向上が期待できることがわかっ た.

3)従来の方法での標準メッシュを固定したままでのデータ 準備と異なり, 本方法ではデータの入力・作成とメッシュ デー夕の格納が分けられているため, デー夕の照査, 修正・ 更新あ容易である，本方法による八ザードマップの作成に 要した時間は, 水俣市の集地区の例では, 従来の方法の 1/10であることが検証できた。

4)数量化理論によるハザードマップの作成にはアイテムと カテゴリー設定のケーススタディが重要である．本方法に よるデー夕の作成や解析用データシートの準備は容易であ るため, くり返し解析が可能であり, 数量化理論解析の精 度と信頼性の向上に大きく貢献することができる。

5) 今後更に多数の現場へ適用することにより本方法を確立 し，より高い精度と信頼性のあるハザードマップの作成手 法を目指していきたいと考えている.

\section{引用 文 献}

1) 久保村圭助・武井昌博 (1971)：数量化による切り取りのり面 の安全度解析, 土木学会論文報告集, No.194, pp.141-150.

2）持永竜一郎・福山俊朗 (1972)：シラスのり面崩壊に関する要 因分析，土木学会論文報告集，No.197, pp.101-110.

3）南部光広・軽部大蔵・浅野雅行(1975)：統計的手法に上る道 路用盛土のり面の安定解析, 土木学会論文報告集, No.241, pp.93-103.

4）沖村孝・杉本博 (1979)：統計的手法による自然斜面崩壊の研 究, 土木学会論文報告集, No.290, pp.159-168.

5）田尻要・中山洋・今泉繁良(1992)：地盤情報データベースを 用いた熊本県中部域斜面災害の解析, 土木学会論文集, Vol. 32, No.2, pp.159-168. 
6) CARRARA,A.(1983): Multivariate models for landslide hazard evaluation, Mathematical Geology, Vol.15, pp.403 -426 .

7）大林成行・小島尚人・藤井克史 (1996)： 衛星マルチスペク トルデータを適用した地すべり危険か所の評価精度の向上, 土木学会論文集, No.534, pp.173-184.

8）仲宗根典子・寺園忠彦(2001)：地盤情報データベースの作成 と斜面崩壊予測への対応，自然災害科学，Vol.20, No.1, pp75-87.

9）国原晃・北園芳人(2001)：斜面崩壊におよぼす微地形変化の 影響, 平成 12 年度土木学会西部支部研究発表講演概要集, pp.A256-257.

10）藤田淳子・北園芳人・柿原孝一郎(2005)：数值地図を用いた 斜面崩壊ハザードマップの精度について, 平成16年度土木学 会西部支部研究発表講演概要集, pp.523-524.

11）北園芳人・仲宗根典子・寺園忠彦 (2001)：地盤情報データベー スの作成と斜面崩壊予測への応用, 自然災害科学, J.JSNDS 20-1, pp.75-87.

12) 林知已夫 (1954): 数量化理論とその応用例, 統計数理研究所 報, Vol.2, No.1, pp.1-30.
13）周国云・江崎哲郎・謝漠文・佐々木靖人(2005)：GISを用い た山地地形から三次元すべり危険斜面を抽出方法の開発と適 用, 応用地質, Vol.46, No.1, pp.28-37.

14）周国云・江崎哲郎・謝漠文・森二郎 (2004)：GIS とモンテカ ルロ法に基づく広域斜面崩壊確率の評価手法, GIS-理論と応 用, Vol.11, No.2, pp.21-31.

15) XIE, M., ESAKI, T., ZHOU, G., MITANI, Y.(2003) : GISbased 3D critical slope stability analysis and landslide hazard assessment, Journal of Geotechnical and Geoenvironmental Engineering, No.12, pp.1109-1118.

16）周国云・江崎哲郎・邱 騁・森二郎(2004)：GISを用いた三次 元斜面安定評価のための単位斜面 (Slope Unit)の抽出, 土と 基礎, Vol.52, No.4, pp.26-28.

17）池谷浩・國友優・中森広道・関谷直也・中村功・宇田川真之・ 廣井修 (2005)：2003年 7 月水俣市土石流災害に扮ける災害情 報の伝達と住民の対応, 東京大学大学院情報学環情報学研究, 調査編, Vol.22, pp.117-239. http://www.soc.toyo.ac.jp/ nakamura/minamata.pdf

(2007年 2 月 22 日受付, 2007 年 9 月 3 日受理)

Jour. Japan Soc. Eng. Geol., Vol.49, No.1, pp.2-12, 2008

\title{
An Advanced Slope Failure Hazard Mapping Method by Combing GIS and Hayashi's Quantification Methods Theory
}

\author{
Guoyun ZHOU, Naomoichi YOKOYA, Guangqi CHENG and Yoshito KITAZONO
}

\begin{abstract}
A new Geographical Information System(GIS)-based slope failure hazard mapping method using Hayashi's quantification methods theory is proposed and applied in a slope failure prone area in Minamata City of Kumamoto Prefecture. In the past, Hayashi's quantification methods theory is often used in slope failure hazard mapping, however, the preparation of larger spatial data is very hard and the work efficiency is low and reliability of the results are doubtful sometime. In this research a series of GIS-based spatial data preparation method is proposed for quantification methods theory analysis and the results of the analysis results can be input into GIS to make hazard map directly. The application of proposed method on Minamata area shows that created hazard map has good agreement with real slope failure condition.
\end{abstract}

Key words : slope failure, quantification methods theory, hazard mapping, Geographic Information System(GIS) 